\title{
IODP Expedition 337: Deep Coalbed Biosphere off Shimokita - Microbial processes and hydrocarbon system associated with deeply buried coalbed in the ocean
}

\author{
Fumio Inagaki ${ }^{1,2}$, Kai-Uwe Hinrichs ${ }^{3}$, Yusuke Kubo ${ }^{4}$, and the IODP Expedition 337 Scientists ${ }^{*}$ \\ ${ }^{1}$ Kochi Institute for Core Sample Research, Japan Agency for Marine-Earth Science and Technology \\ (JAMSTEC), Monobe B200, Nankoku, Kochi 783-8502, Japan \\ ${ }^{2}$ Research and Development Center for Ocean Drilling Science (ODS), JAMSTEC, Yokohama 236-0001, Japan \\ ${ }^{3}$ MARUM Center for Marine Environmental Sciences, University of Bremen, Leobener Strasse, \\ 28359 Bremen, Germany \\ ${ }^{4}$ Center for Deep-Earth Exploration (CDEX), JAMSTEC, Showa-machi 3173-25, Kanazawa-ku, Yokohama, \\ Kanagawa 236-0001, Japan \\ *A full list of authors appears at the end of the paper.
}

Correspondence to: Fumio Inagaki (inagaki@jamstec.go.jp) and Kai-Uwe Hinrichs (khinrichs@uni-bremen.de)

Received: 8 February 2016 - Revised: 9 June 2016 - Accepted: 14 June 2016 - Published: 27 June 2016

\begin{abstract}
The Integrated Ocean Drilling Program (IODP) Expedition 337 was the first expedition dedicated to subseafloor microbiology that used riser-drilling technology with the drilling vessel Chikyu. The drilling Site C0020 is located in a forearc basin formed by the subduction of the Pacific Plate off the Shimokita Peninsula, Japan, at a water depth of $1180 \mathrm{~m}$. Primary scientific objectives during Expedition 337 were to study the relationship between the deep microbial biosphere and a series of $\sim 2 \mathrm{~km}$ deep subseafloor coalbeds and to explore the limits of life in the deepest horizons ever probed by scientific ocean drilling. To address these scientific objectives, we penetrated a $2.466 \mathrm{~km}$ deep sedimentary sequence with a series of lignite layers buried around $2 \mathrm{~km}$ below the seafloor. The cored sediments, as well as cuttings and logging data, showed a record of dynamically changing depositional environments in the former forearc basin off the Shimokita Peninsula during the late Oligocene and Miocene, ranging from warm-temperate coastal backswamps to a cool water continental shelf. The occurrence of small microbial populations and their methanogenic activity were confirmed down to the bottom of the hole by microbiological and biogeochemical analyses. The factors controlling the size and viability of ultra-deep microbial communities in those warm sedimentary habitats could be the increase in demand of energy and water expended on the enzymatic repair of biomolecules as a function of the burial depth. Expedition 337 provided a test ground for the use of riser-drilling technology to address geobiological and biogeochemical objectives and was therefore a crucial step toward the next phase of deep scientific ocean drilling.
\end{abstract}

1

Subseafloor sediments harbor a remarkable number of microbial cells, with its concentrations decreasing logarithmically with increasing burial depth (Parkes et al., 1994; D'Hondt et al., 2004; Lipp et al., 2008; Kallmeyer et al., 2012). Active microbial populations exist at great depths below the ocean floor, which can only be explored by scientific ocean drilling. For example, the Integrated Ocean Drilling Program (IODP) Expedition 317 found microbial cells in sediments of the Canterbury Basin, off the coast of New Zealand, down to 1922 meters below the seafloor (m b.s.f.) (Site U1352, $344 \mathrm{~m}$ water depth; Ciobanu et al., 2014). However, the extent of the deep biosphere and factors limiting life at its lower bound- 
aries remain largely unknown. For similar reasons, microbial ecosystems in marine subsurface hydrocarbon reservoirs on the continental margin are among the least characterized systems on Earth. In fact, our knowledge base of the interactions of the deep biosphere with offshore hydrocarbon reservoirs has long suffered from the highly limited opportunities to target natural gas and oil fields with scientific ocean drilling initiatives. Despite the biogeochemical significance of hydrocarbon reservoirs for the global carbon cycle (Head et al., 2003; Jones et al., 2008), there have been no studies of coal layers that are deeply buried in the subseafloor, mainly because of the safety regulations related to hydrocarbon gasrelated hazards during non-riser-type drilling. In continental sediments, large quantities of gaseous hydrocarbons and their derivatives (e.g., $\mathrm{H}_{2}$, organic acids) are potentially generated via thermogenic and/or biogenic degradation processes of deeply buried organic matter such as lignite coals (e.g., Jones et al., 2008; Glombitza et al., 2009; Strąpoć et al., 2008, 2011). Such diagenetic products are potential nutrient and energy sources that support energy-yielding redox reactions mediated by deep subseafloor microbial communities. Hence, coalbeds and microbial life may influence characteristics of dissolved gases and organic matter in the subsurface and result in the accumulation of gas hydrates in shallow sedimentary strata. The metabolic characteristics of organic matter degradation and the fluxes of secondary metabolites, however, still remain largely unknown (Hinrichs et al., 2006; Hinrichs and Inagaki, 2012). To explore the limits of microbial life and the biosphere and understand microbial processes in the deeply buried coalbeds, Expedition 337 examined the hydrocarbon system associated with deeply buried coalbeds off the Shimokita Peninsula, Japan, in the northwestern Pacific using the riser-drilling system of Chikyu (Inagaki et al., 2012).

\section{Geological background}

The drilling Site C0020 is located in a forearc basin formed by the subduction of the Pacific Plate $\left(\sim 8 \mathrm{~cm}_{\text {year }}{ }^{-1}\right.$, westnorthwest plate motion vector: Seno et al., 1996) beneath northeastern Honshu, Japan (Fig. 1). During the Chikyu shakedown cruise CK06-06 in 2006, 365 m of sediment core were recovered from the upper sedimentary section at Japan Agency for Marine-Earth Science and Technology (JAMSTEC) Site C9001 ( $41^{\circ} 10.5983^{\prime}$ N, $142^{\circ} 12.0328^{\prime}$ E, $1180 \mathrm{~m}$ water depth, i.e., the same location as IODP Site C0020), approximately $80 \mathrm{~km}$ off the coast of Shimokita Peninsula of Japan (Aoike, 2007). Preliminary biostratigraphic age models indicated very high sedimentation rates, ranging from 54 to $95 \mathrm{~cm} \mathrm{kyr}^{-1}$, and an approximate core-bottom age of 640 ka (Aoike, 2007; Aoike et al., 2010; Domitsu et al., 2010). During the same cruise, riser drilling was also tested down to $647 \mathrm{~m}$ b.s.f. without coring, and 20" casings were installed down to $511 \mathrm{~m}$ b.s.f., and then the riser hole was sus-

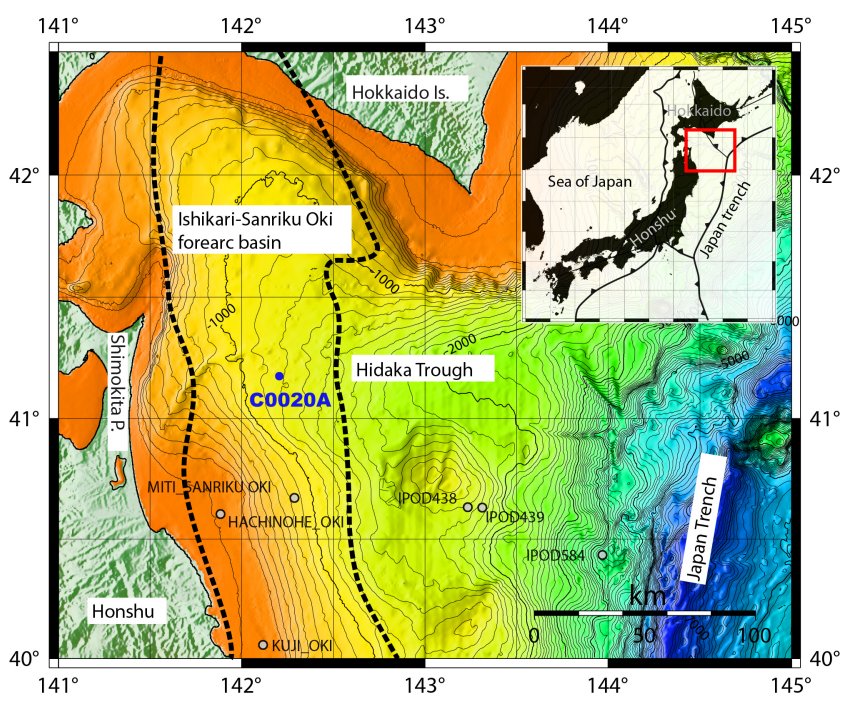

Figure 1. Bathymetric map of IODP Site C0020 (JAMSTEC Site C9001) and existing drill holes off the Shimokita Peninsula, Japan. Inset map shows plate configuration around Japanese islands and the location of the index map (gray square). This figure is slightly modified from Fig. S1 in Inagaki et al. (2015), and reprinted with permission from American Association for the Advancement of Science (AAAS).

pended for future operations including the IODP Expedition 337.

The Hidaka Trough, a sedimentary basin formed by subsidence in the drilling area, originates just offshore southwest of Hokkaido and extends to the Japan Trench. Along the coastal area of the Shimokita Peninsula, both sedimentary and volcanic rocks younger than Late Cretaceous lie scattered on Triassic to Early Cretaceous sedimentary rocks or Cretaceous granites. Several scientific drilling expeditions have been carried out off the Shimokita Peninsula: Deep Sea Drilling Program (DSDP) Legs 56 and 57 in 1977, Leg 87 in 1982, and Ocean Drilling Program (ODP) Leg 186 in 1999. In addition, well data are available from hydrocarbon drilling exploration carried out between 1977 and 1999 (Japan Natural Gas Association and Japan Offshore Petroleum Development Association, 1992; Osawa et al., 2002). Seismic profiles around Site C0020 show pull-up blanking reflections below bottom-simulating reflectors at around $360 \mathrm{~m}$ b.s.f., suggesting the occurrence of methane hydrates in shallow sedimentary realms and a strong upward flux of free hydrocarbon gases from deep reservoirs. A thick and prominent Quaternary sedimentary unit onlaps to a Pliocene unit and is thought to be composed mainly of alternating beds of mud and sand with intercalations of thin volcanic tephras and locally developed gravel/sand layers. The Pliocene unit consists primarily of alternating beds of mudstone and sandstone. Below these relatively recent formations, there are sedimentary deposits ranging from Cretaceous to Miocene in age that are cut by many landward-dipping normal faults. The presence 
of coal formations underneath the seafloor has been confirmed by the natural gas drilling exploration at nearby site MITI Sanriku-Oki, approximately $50 \mathrm{~km}$ southward from Site C0020 (Fig. 1; see Osawa et al., 2002). Sonic logging data in the MITI Sanriku-Oki well showed that three major tuff layers involving coal layers with 30,45 , and $80 \mathrm{~m}$ thickness (40-60\% total organic carbon (TOC) in lignite coal layer and $0.5-2 \%$ TOC in tuffs) are present in Eocene and Pliocene-Upper Cretaceous horizons, in which vitrinite reflection values (Ro) were in the range between 0.5 and $0.7 \%$, indicating relatively immature coals. The in situ temperatures are well within the range of the habitable zone of microbes, based on the reported thermal gradient of $22.5^{\circ} \mathrm{C} \mathrm{km}^{-1}$ (Osawa et al., 2002).

\section{Microbiological background}

During the Chikyu shakedown expedition CK06-06 at the drilling site later occupied during Expedition 337, the shift of microbial communities in the first use of riser-drilling mud tanks and circulated drilling fluids was examined through cultivation and cultivation-independent microbiological studies (Masui et al., 2008). Despite the high alkalinity of the riser-drilling mud ( $\sim \mathrm{pH} 10)$, the predominance of Xanthomonas DNA as well as the potential growth of facultatively anaerobic and halophilic bacteria Halomonas were observed in the mud tank sample.

Microbial cell numbers in $365 \mathrm{~m}$ sediment from Site C9001 were evaluated by the fluorescent image-based automated cell count system, showing that the sediment contained abundant microbial cells with counts over $10^{7} \mathrm{~mL}^{-1}$ down to 365 m b.s.f. (Morono et al., 2009; Morono and Inagaki, 2010). The relative abundance of Bacteria and Archaea was studied by quantitative polymerase chain reaction (PCR) and slot-blot hybridization techniques, suggesting a significant contribution of Archaea to the subseafloor microbial biomass (average 30-40\% at DNA level) (Lipp et al., 2008). Using a deep sediment sample from Site C9001, carbon and nitrogen incorporation rates of sedimentary microbes were studied using nano-scale secondary-ion mass spectrometry (NanoSIMS), indicating that the deeply buried microbial cells are indeed alive and capable of carbon and nitrogen uptake into their cellular biomass (Morono et al., 2011). Taxonomic compositions of microbial communities in $365 \mathrm{~m}$ of sediment cores were investigated by analyzing PCR-amplified 16S rRNA and some key functional genes (Futagami et al., 2009; Morono et al., 2014; Aoki et al., 2015; Nunoura et al., 2016) as well as the metagenomic sequences (Kawai et al., 2014, 2015), indicating the occurrence of microbial communities that have been often detected in organic-rich sediments on the Pacific margins (e.g., Inagaki et al., 2003, 2006), such as bacterial members of the phyla "Atribacteria", Chloroflexi, Planktomycetes, and Firmicutes, and archaeal members of the "Bathyarchaeota" (previously classified as the Miscellaneous Crenarchaeota Group, MCG), Marine Benthic Group-B (alternatively, Deep-Sea Archaeal Group (DSAG) or "Lokiarchaeota"), and South African Gold Mine Euryarchaeota Group (SAGMEG).

Cultivation of aerobic and anaerobic microorganisms has been conducted at Site C9001 and a variety of microbes and their enzymatic activities were observed (Kobayashi et al., 2008). Using a continuous-flow bioreactor system called down-flow hanging sponge reactor, phylogenetically diverse, strictly anaerobic microbes were also successfully cultivated, including methanogens such as the genera Methanobacterium, Methanoccoides, and Methanosarcina (Imachi et al., 2011). Several attempts of traditional batch-type cultivations also successfully led to the pure culture isolation of several subseafloor anaerobic microbes, including new Bacterioidetes species of Geofilum rubicundum (Miyazaki et al., 2012) and Sunxiuqinia faeciviva (Takai et al., 2012), new Spirochaetes species of Spirochaeta psychrophila and Sphaerochaeta multiformis (Miyazaki et al., 2014a, b), and a new species of a new genus of Pelolinea submarina within the phylum Chloroflexi (Imachi et al., 2014).

\section{Scientific objectives}

During Expedition 337, we tackled a number of fundamental questions regarding deep subseafloor hydrocarbon systems. For example:

- What role does subsurface microbial activity play in the formation of hydrocarbon reservoirs?

- Do deeply buried hydrocarbon reservoirs, such as natural gas formations and coalbeds, act as geobiological reactors that sustain subsurface life by releasing nutrients and carbon substrates?

- Do the conversion and transport of hydrocarbons and other reduced compounds influence biomass, diversity, activity, and functionality of deep subseafloor microbial populations?

- What are the fluxes of both thermogenically and biologically produced organic compounds and how important are these for the carbon budgets in the shallower subsurface and the ocean?

- What paleoenvironmental information and sedimentary regimes are recorded at Site C0020?

- What is the extent of the subseafloor biosphere? What environmental factors define the lower boundaries of the biosphere? 


\section{Expedition summaries}

\subsection{Coring, drilling, and logging operations}

The Chikyu left Hachinohe Port to Site C0020 on 26 July 2012. The corrosion cap of Hole C9001D, which was drilled to $647 \mathrm{~m}$ b.s.f. and cased to $511 \mathrm{~m}$ b.s.f. during the Chikyu shakedown cruise in 2006, was retrieved at the surface on 27 July. Ten transponders were installed on the seafloor by a remotely operated vehicle on $28 \mathrm{July}$, and failure mode effect analysis for acoustic position reference system was completed on 29 July.

While the surface pressure test of the blow out preventer (BOP) was being carried out, the science party was shuttled on board by helicopter flights on 31 July. Technical problems were found during the function test of the BOP and troubleshooting continued until 8 August. A successful BOP landing was confirmed on 11 August. Extensive BOP tests were carried out until completion of the pressure test on 14 August. Subsequently, riser drilling started. Due to the delay in operations, planned spot-coring in the interval 647$1220 \mathrm{~m}$ b.s.f. was canceled and instead a $17-1 / 2^{\prime \prime}$ hole was established and cemented to a depth of $1220 \mathrm{~m}$ b.s.f. On $16 \mathrm{Au}-$ gust, we encountered total mud loss at $2375 \mathrm{~m}$ drilling depth below rig floor (DRF). After spotting lost circulation mud twice, mud loss rate decreased to $0.8 \mathrm{~m}^{3} \mathrm{~h}^{-1}$. A decision to continue drilling with seawater gel mud was made. Drilling resumed on 18 August and reached at $2471.5 \mathrm{~m}$ DRF (i.e., $1263 \mathrm{~m}$ b.s.f.); to this depth $13-3 / \mathrm{8}^{\prime \prime}$ casing was installed.

Coring operation started on 25 August. While riser drilling continued, spot cores were taken by rotary core barrel (RCB) until core 7R hit a low rate of penetration interval at $1604.0 \mathrm{~m}$ b.s.f. The core included gravels of volcanic origin and showed different lithology from previous cores. To retrieve core samples at this depth, an industry-type large diameter core (LDC) was tested. The LDC operation was, however, stopped before reaching the targeted $27 \mathrm{~m}$ of drilling advance, because an increase in pump pressure and no further penetration indicated core jamming. The LDC was recovered on deck on 30 August and the recovered core was $10.0 \mathrm{~m}$ from $21.5 \mathrm{~m}$ of advance. The core was cut into $1.0 \mathrm{~m}$ long sections at the middle pipe rack and transferred to the laboratory. Spot coring resumed with RCB and cores $9 \mathrm{R}$ to $14 \mathrm{R}$ were taken before continuous coring through the coalbearing horizons started at $1919 \mathrm{~m}$ b.s.f. After four consecutive RCB cores were recovered, the drill bit appeared to be worn out. Consequently, it was decided to change the drill bit.

After coring of core $18 \mathrm{R}$, it was also decided that we continue RCB coring and cancel a planned operation of the LDC. The new drill bit was installed and coring operations resumed on 4 September. Another seven consecutive RCB cores were taken from 1950 to $2003.5 \mathrm{~m}$ b.s.f. Core recovery was high, and coal-bearing sequences were obtained. With the successful sampling of various lithologies within and around the coal-bearing formation, our operational mission in this interval was fulfilled, and we then advanced the borehole by drilling and spot coring in $100 \mathrm{~m}$ intervals to more completely examine the hydrocarbon system and explore the limits of life at greater depths. We reached the terminal depth of Hole C0020A at $2466 \mathrm{mb}$ b.s.f. on 9 September, exceeding the previous deepest hole of scientific ocean drilling (i.e., 2111 m b.s.f., Hole 504B off Costa Rica, ODP Leg 148). The core recovery through riser drilling was remarkably high, often close to $100 \%$, even at great burial depths of $2000 \mathrm{~m}$ b.s.f. and deeper.

The condition of the riser borehole was excellent, allowing for close-to-perfect acquisition of downhole wireline logging data. After pulling out of the hole, wireline-logging operation started. Logging run 1 (PEX: platform express) started on 10 September, followed by runs 2 (FMI: formation microimager) and 3 (CMR: combinable magnetic resonance). High-permeability layers were selected for the Modular Formation Dynamics Tester (MDT) based on the results from the first three runs. After a wiper trip, run 4 (MDT-GR: MDTgamma ray) started on 12 September. Pretests for fluid mobility and formation pressure measurements were carried out at 31 horizons. Formation fluid samples were taken by the Schlumberger's QuickSilver MDT-Probe at six horizons of high mobility, and the six bottles were recovered on deck on 14 September. The sample bottles were delivered to the laboratory during the following run 5 (VSP: vertical seismic profile). The last run was completed on 15 September, ending scientific operation on the rig floor.

\subsection{Lithostratigraphy and biostratigraphic age}

Four distinct lithologic units were identified at Site C0020 on the basis of combined analysis of cuttings and cores, and assisted by inspection of X-ray computed tomography (CT) scan images and wireline-logging data; 14 coal layers were confirmed between 1825 and $2466 \mathrm{~m}$ b.s.f. On-board micropaleontology included diatoms, calcareous nannofossils, organic-walled dinoflagellate cysts (dinocysts), pollen, and spores, indicating a probable age of late Oligocene to early Miocene at the base at $2466 \mathrm{~m}$ b.s.f. A stratigraphic column of the borehole is provided in Fig. 2. From top to base, the following units were described (Inagaki et al., 2012; Gross et al., 2015).

- Unit I (647-1256.5 mb.s.f.) consists primarily of diatom-bearing silty clay. This unit resulted from sedimentation in an offshore marine environment. Diatoms were best and most abundantly preserved in Unit I among monitored microfossils together with predominantly heterotrophic dinocysts. Diatom floras in Unit I are consistent with a Pliocene cool-water continental shelf succession. Heterotrophic dinocyst communities feeding off diatom blooms are suggestive of elevated marine productivity. 


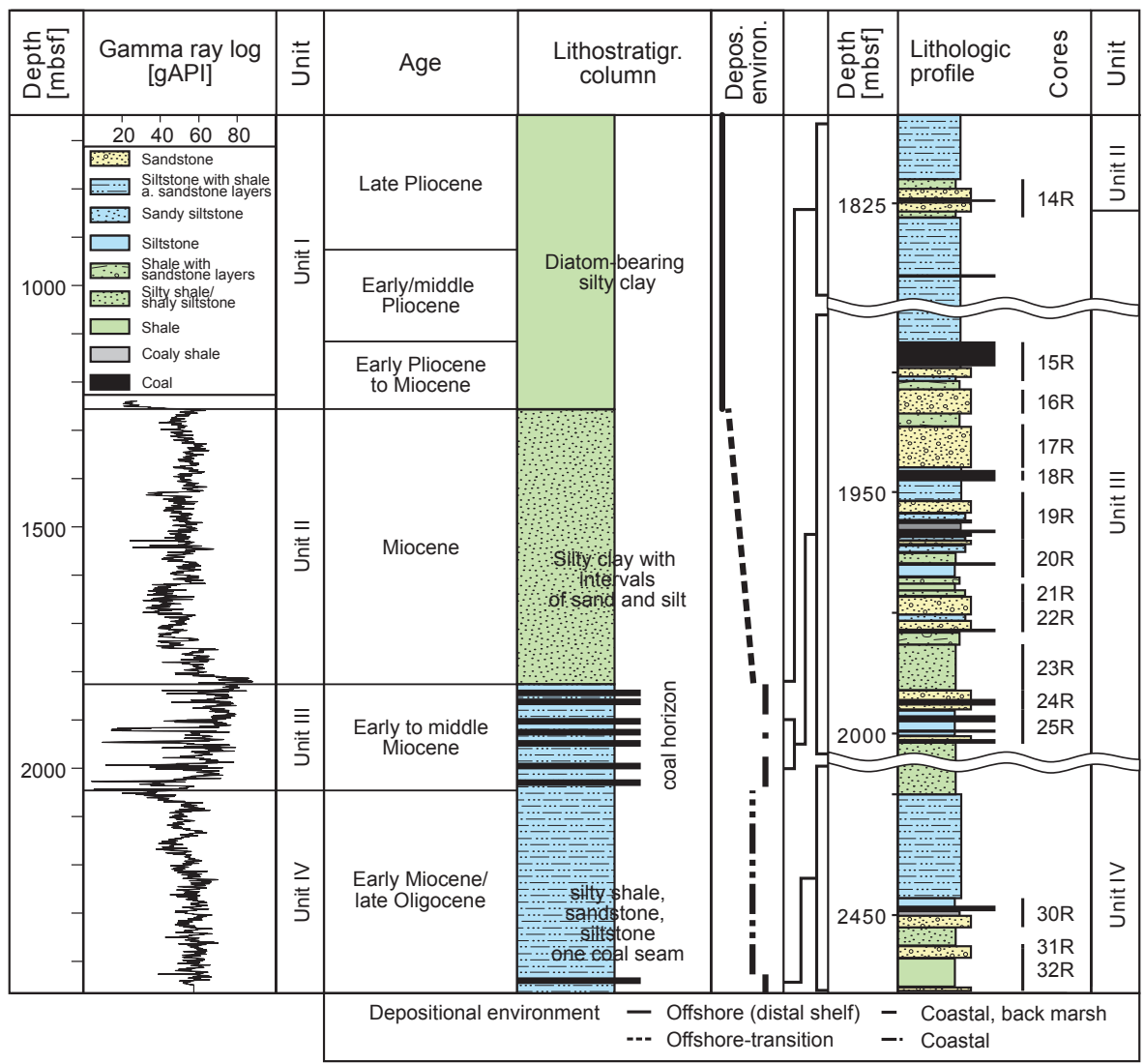

Figure 2. Lithologic profile of Hole C0020A based on macroscopic observation of cuttings (middle and right column) and cores (right column) recovered during Expedition 337. Gamma-ray log and positions of spot-cores are also plotted. This figure is slightly modified from Fig. 2 in Gross et al. (2015), and reprinted with permission from Elsevier.

- Unit II (1256.5-826.5 m b.s.f.) consists mostly of silty shale with some interspersed intervals of sandstone and siltstone. Cuttings samples show a lower amount of sand and an increase of silt at the Unit I/II boundary. The abundance of biogenic siliceous material, glauconite, and plant remains additionally differentiate Unit II from the overlying unit. Unit II was subdivided into two different subunits, sandstone and siltstone associated with marine fossiliferous material (Subunit IIa; $1256.5-1500 \mathrm{~m}$ b.s.f.) and organic-rich shale and sandstone associated with plant remains (Subunit IIb; 1500$1826.5 \mathrm{~m}$ b.s.f.). The upper part of Unit II represents an offshore paleoenvironment, possibly close to the shelf margin; with increasing depth the paleoenvironment gradually changes into a shallow marine setting. The bottom part of Unit II is situated in the intertidal zone. This shift is consistent with microfossil assemblages that exhibit few identifiable diatoms and poor dinocysts; reworked dinocyst in Unit II, as in deeper units, have Paleogene ages that broadly fall in the range of earlymiddle Eocene through to late Oligocene. Pollen and spores are moderately well represented but are abundant near the base of Unit II, consistent with an increasing terrestrial influence in shallow marine sediments.

- Unit III (1826.5-2046.5 mb.s.f.) is dominated by several coal horizons, which we subdivided into coaly shales, siltstones, and sandstones. Almost all coal horizons consist of fine-detritic to xylodetritic coal with some layers of xylitic coal. Water content, color, and vitrinite reflectance measurements of the coal suggest that the coal has low maturity. Bioturbation and sedimentary features like flaser bedding, lenticular bedding or cross-bedding suggest a near-shore depositional environment with tidal flats and tidal channels. The presence of siderite bands at the bottom of this unit suggests a back barrier marine environment in combination with wetlands (e.g., salt marsh or swamp). Small terrestrial influence (e.g., siderite grains) might occur within sand bodies that overlie coal horizons. This could be due to channels from deltaic environments. Unit III contains excellently preserved pollen and spore assemblages in the coals and associated terrestrial to coastal shallow marine sediments. However, dinocysts are scarce and contain few useful biostratigraphic markers. The pollen 
floras tentatively suggest a likely age of early-middle Miocene for Unit III.

- Unit IV (2046.5-2466 m b.s.f.) is dominated by silty shales in the upper part, sandstone, intercalated with siltstone, and shale associated with sand in the middle part and with silt and a thin coal layer in the lower part. Wireline logs and cuttings samples suggest a thick homogeneous shale layer between the Unit III boundary and core $27 \mathrm{R}$ at $2200 \mathrm{~m}$ b.s.f. The depositional environment of Unit IV resembles that of Unit III, except that the former contains only one thin coalbed layer. Like Unit III, Unit IV experienced high-frequency fluctuations of the depositional environment. Within a few meters, there are sediments related to tidal flats and tidal channels, which are overlain by organic-rich material of a marsh that resulted in formation of peat. The pollen floras place a maximum age of late Oligocene for the base of Unit IV.

\subsection{Physical properties and downhole logging}

A series of physical property measurements were performed on core and cuttings samples from Site C0020. Gamma-ray attenuation density, magnetic susceptibility, natural gamma radiation, $P$ wave velocity, and noncontact electrical resistivity were measured with the multi-sensor core logger. Measurements of thermal conductivity were made mostly on working-half cores. Discrete samples taken from workinghalf and some whole-round core samples were applied to moisture and density (MAD) analyses to calculate the porosity, bulk density, grain density, and water content. $P$ wave velocity analysis and electrical impedance analysis were made on cubic discrete samples. Cuttings samples were also applied to MAD analysis. Cuttings samples were separated into four categories: original bulk and sieved size categories of $>4.0,1.0-4.0$, and $0.25-1.0 \mathrm{~mm}$. Large-size fraction of the cuttings samples were cut off cubic samples and applied to the $P$ wave velocity analysis and the electrical impedance analysis. Anelastic strain recovery analysis was made on some whole-round cores. Vitrinite reflectance analysis was performed on some coaly samples, indicating generally low maturity of coal. Porosity of siltstone, sandstone, and shale gradually decreased with increasing depth (Fig. 3). Porosity corresponds to lithologic variation, with carbonate-cemented sandstone and siltstone having much lower values than noncemented sandstone and siltstone. The porosity of coal does not deviate from the major trend of the other lithologies, although the coal may change the figures because of decompaction after the recovery. The cuttings also show a gradual decrease in porosity but have generally higher values than the core samples. Discrete core samples are likely more representative of in situ porosity than cuttings.

Due to the very good borehole condition, logging data were excellent quality, resulting in straightforward interpre-

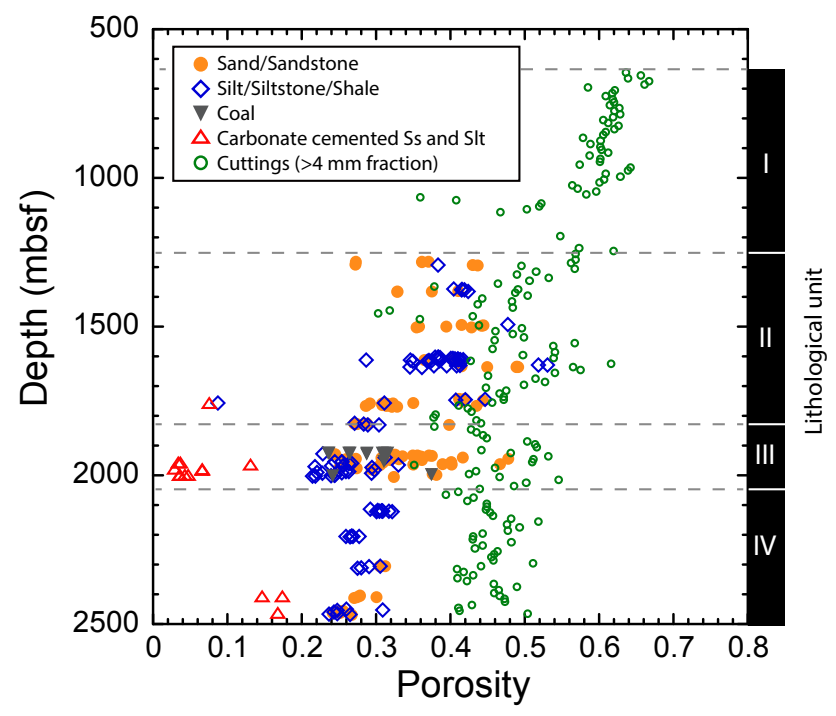

Figure 3. Distribution and lithological variation of porosity in discrete core samples with comparison of cuttings at Site C0020 (Inagaki et al., 2012; Tanikawa et al., 2016). Note that discrete core samples can be more representative for in situ porosity than porosity of cuttings.

tation of these logging data with respect to lithology. The logging data generally compensated for the lack of cores, and ultimately led to the establishment of a database that fully reconstructs the sedimentation history at Site C0020 (Inagaki et al., 2012). Borehole temperature was measured with two types of logging tools. The maximum temperature at the bottom of Hole C0020A was estimated by examining the temperature build-up pattern during the logging operation. The estimated temperature gradient was $24.0^{\circ} \mathrm{C} \mathrm{km}^{-1}$ or slightly higher (Tanikawa et al., 2016).

\subsection{Microbiology and biogeochemistry}

Expedition 337 was the first riser-drilling expedition to incorporate extensive on-board microbiological and biogeochemical analyses. All microbiological samples for the cell count, cultivation, and molecular studies were obtained from the center of non-disturbed whole-round core samples after inspection by X-ray CT scan and perfluorocarbon tracer assays for contamination from drill fluids (see Lever et al., 2006; Inagaki et al., 2012) immediately after core recovery. The samples were then processed with special aseptic care in either the microbiology laboratory on the Chikyu or the JAMSTEC Kochi Institute for Core Sample Research. Since the target sedimentary habitat is strictly anaerobic, all the cored materials recovered on board were immediately processed for shipboard and shore-based microbiological analyses under the $\mathrm{N}_{2}$-flushed anaerobic condition. For the composition of gases above, in and below the coalbed, about one million discrete data points could be continuously recorded by mud gas monitoring during riser-drilling operation. Mud gas mon- 


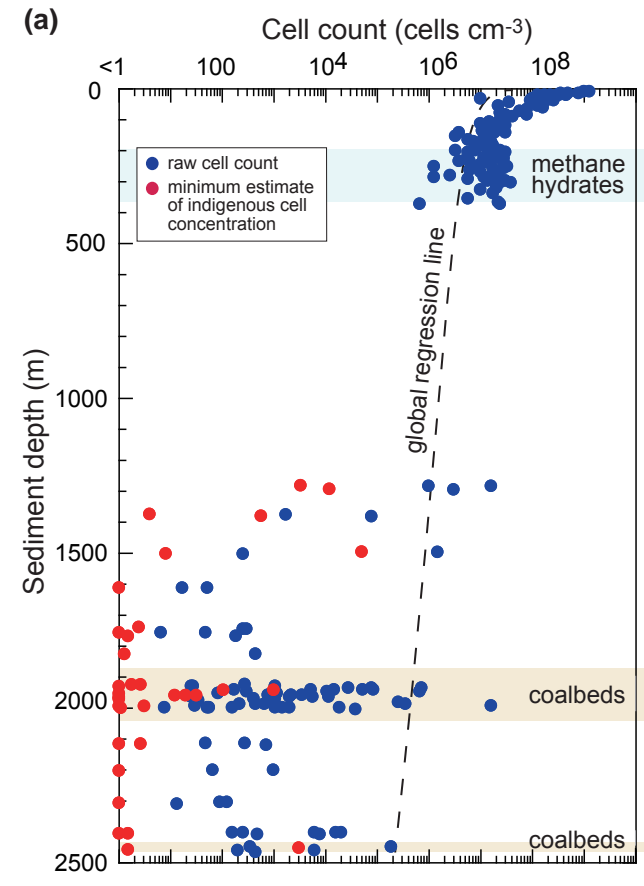

(b) $\mathrm{\delta D}-\mathrm{CH}_{4}(\%$ vs SMOW)

(c) $\quad \mathrm{C}_{1} / \mathrm{C}_{2}$

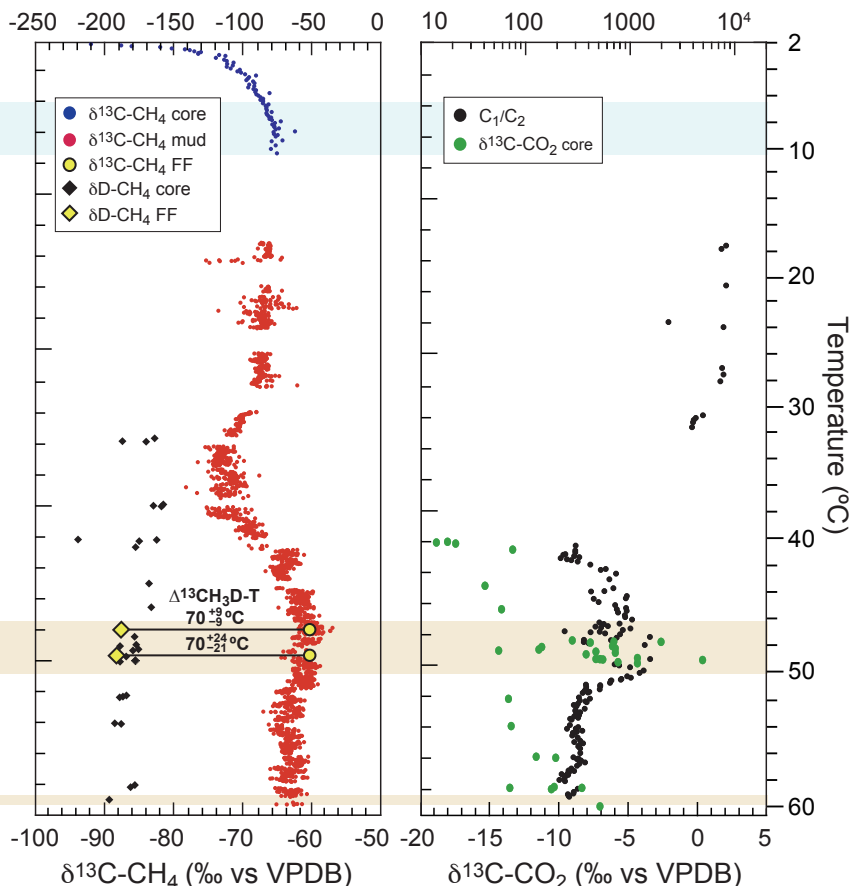

Figure 4. Depth profiles of (a) microbial cell concentrations, (b) $\delta^{13} \mathrm{C}$ and $\delta \mathrm{D}$ of methane, and (c) $\mathrm{C}_{1} / \mathrm{C}_{2}$ ratios and $\delta^{13} \mathrm{C}$ of $\mathrm{CO}_{2}$ at Site $\mathrm{C} 0020$ (Inagaki et al., 2015). Raw data of fluorescence image-based cell counts and the minimum estimates of indigenous cell concentrations corrected for contamination based on molecular data are shown by blue and red symbols in (a), respectively. The minimal quantification limit for raw cell counts was $1.43 \times 10^{2}$ cells cm $\mathrm{cm}^{-3}$; i.e., the upper $95 \%$ confidence interval of negative background. All $\delta^{13} \mathrm{C}$ and $\delta \mathrm{D}$ in $(\mathbf{b})$ and (c) are in \%o versus Vienna Pee Dee belemnite (VPDB) and Standard Mean Ocean Water (SMOW), respectively. The $\Delta^{13} \mathrm{CH}_{3} \mathrm{D}-\mathrm{T}$ values designate the apparent equilibrium temperatures derived from measurements of a clumped isotopologue of methane $\left({ }^{13} \mathrm{CH}_{3} \mathrm{D}\right)$ in discrete formation fluid (FF) samples obtained using the QuickSilver MDT-Probe in situ. Temperature in (c) is based on the temperature gradient of $24.0^{\circ} \mathrm{C} \mathrm{km}^{-1}$ determined by downhole logging. Cell concentration and $\delta^{13} \mathrm{C}$ of methane in the upper sedimentary sequence (0-365 m b.s.f.) were obtained at the same location during the JAMSTEC Chikyu shakedown expedition CK06-06 in 2006. This figure is slightly modified from Fig. 1 in Inagaki et al. (2015), and reprinted with permission from AAAS.

itoring was supplemented by gas analysis in more than 100 samples from cuttings and cores.

Within the lithological setting of the Shimokita coalbed biosphere, where environmental conditions changed drastically after shallow coastal sediments subsided below sealevel since the Miocene, we have detected the most deeply buried microbial communities studied to date (Inagaki et al., 2015). Microbial cells were detached from sediments by a multi-layer density gradient technique (Morono et al., 2013), and then their concentration was determined by both manual and computer-based microscopic image analyses (Morono et al., 2009, 2013; Morono and Inagaki, 2010). The cell count analysis revealed that cell concentrations in deep sediments below $\sim 1.5 \mathrm{~km}$ b.s.f. were drastically lower than those predicted by the slope of the global regression line; concentrations typically ranged from $\sim 10^{2}$ to $10^{3}$ cells cm$^{-3}$ with local peaks in coal-bearing horizons (Fig. 4a). These extremely low cell concentrations, which are even lower than those in ultra-oligotrophic sediments of the South Pacific Gyre (D'Hondt et al., 2015), suggest that our drilling opera- tions have approached the lower boundary of the deep subseafloor biosphere at this site. Despite the very low cell concentrations, microbial formation of methane via $\mathrm{CO}_{2}$ reduction was indicated by isotopic data of methane and carbon dioxide (Fig. 4b and c), methanogenic biomarkers, cultivation, and gas composition results throughout the entire drilled sedimentary sequence (Inagaki et al., 2015). The occurrence of in situ methanogenesis was further demonstrated by the successful cultivation of methanogenic microbial communities using an anaerobic bioreactor at $40^{\circ} \mathrm{C}$ (Fig. 5); the resulting enrichments include hydrogenotrophic methanogens closely related to Methanobacterium subterraneum. Direct biomarker evidence for the activity of methanogenesis in $\sim 2 \mathrm{~km}$ deep coalbeds is also provided by the detection of intact coenzyme $\mathrm{F}_{430}$ in core samples, which is an essential biomolecule in methanogenesis pathway. Moreover, in situ production of methane is supported by measurements of a multiply substituted clumped isotopologue $\left({ }^{13} \mathrm{CH}_{3} \mathrm{D}\right)$ in methane extracted from in situ formation fluids obtained by using the Schlumberger's QuickSilver MDT-Probe, suggest- 


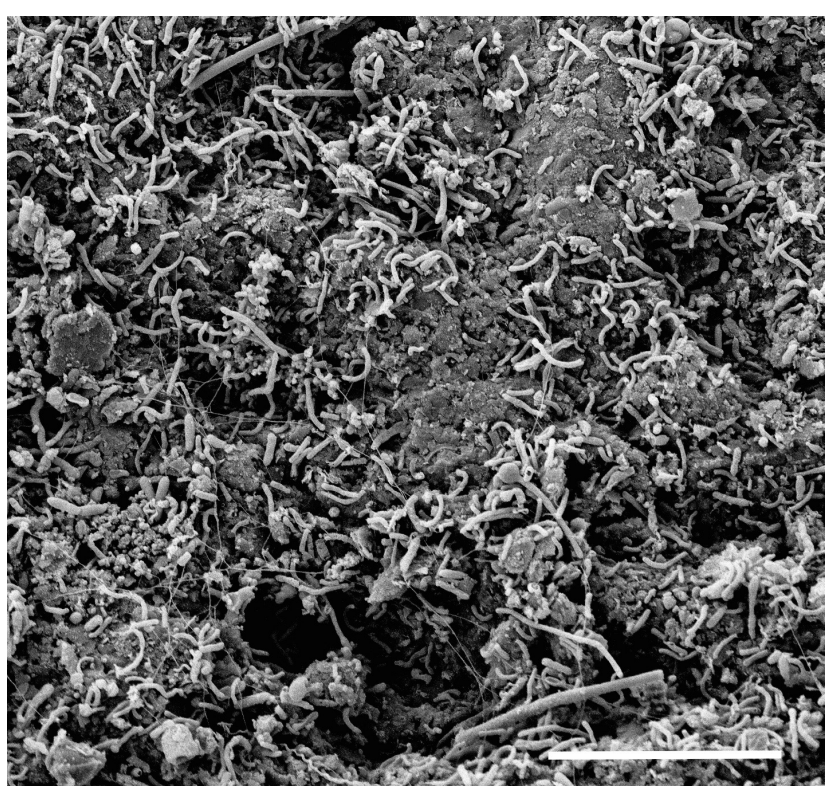

Figure 5. A scanning electron micrograph of an anaerobic, methanogenic microbial community enriched in $\sim 2 \mathrm{~km}$ deep subseafloor coal samples. The cultivation experiment was carried out using a continuous-flow bioreactor at $40{ }^{\circ} \mathrm{C}$ for 694 days. Bar: $10 \mu \mathrm{m}$. (Photo: Hiroyuki Imachi, JAMSTEC)

ing clumped-isotope equilibrium temperatures for biogenic methane at $\sim 70{ }^{\circ} \mathrm{C}$, which are notably lower than those observed for thermogenic methane in excess of $150{ }^{\circ} \mathrm{C}$ (Stolper et al., 2014; Wang et al., 2015).

By comparison of $16 \mathrm{~S}$ rRNA gene sequences (i.e., V1$\mathrm{V} 3$ region) from control samples to those derived from experimental samples, we determined the taxonomic composition of indigenous bacterial communities. The data indicated that deep bacterial communities (1278-2458 m b.s.f.) differ profoundly from communities at shallower depths $(0-$ 364 m b.s.f.) (Fig. 6). For example, no or very low proportions of sequence reads affiliated with the phyla Chloroflexi or "Atribacteria", both globally abundant groups in subseafloor sediments on ocean margins (Inagaki et al., 2003, 2006), were detected in the deep layers. Instead, the sequence assemblage in deep layers is represented, in decreasing order of abundance, by the genera Alishewanella, Patulibacter, Thiobacillus, Gemmatimonas, Actinomycetospora, Spirosoma, Terriglobus, and the phylum Tenericutes relatives, most of which are heterotrophic bacteria commonly found in forest soils or organic-rich freshwater environments (Inagaki et al., 2015; Fig. 6).

The samples and data from Site C0020 offer the unique opportunity to explore the lower margins of the habitable zone, i.e., the bottom of the deep biosphere, and to search for clues regarding physical, chemical, and bioenergetic factors that limit microbial life below $\sim 1.5 \mathrm{~km}$ b.s.f. at Site C0020. Physical factors such as low porosity and permeability may influence fluxes of water, nutrients, and metabolic products in the deeply buried sediments at Site C0020. In addition, an important factor controlling the extent of microbial communities could be the increase in energy expanded on the repair of biomolecules. Substantial increases in both modeled biomolecule-damaging rates (abiotic amino acid racemization, DNA depurination) coincide with a sharp drop in cell concentrations at Site C0020 (Fig. 7). Possibly, the increased energetic cost of biomolecule repair results in a higher demand of water and energy for the damage fixation and/or new biosynthesis (Lever et al., 2015), explaining why the environment explored during Expedition 337 appeared to be situated close to the lower boundary of the deep subseafloor biosphere.

Taken together, the major goals of the on-board geology, microbiology, and biogeochemistry programs were successfully accomplished, and extensive shore-based studies using samples and data collected during Expedition 337 will significantly expand our knowledge of the deep, dark, and old subseafloor biosphere and contribute to the better understanding of the biogeochemical carbon cycle.

\section{Technical advances}

During Expedition 337, our major operational objectives to meet the scientific goals have been successfully accomplished through use of the riser-drilling system of the Chikyu. The bottom depth of Hole C0020A is $2466 \mathrm{~m}$ b.s.f., extending the previous maximum penetration depth in scientific ocean drilling by $355 \mathrm{~m}$ and providing evidence of subseafloor life in the deepest samples retrieved to date. The new on-board facilities such as the mud gas-monitoring laboratory and the radioisotope laboratory were successfully implemented and strongly contributed to the success of Expedition 337. This first deep riser drilling expedition exploring deep life had important strategic value in that this was the first time that the impact of commercially used drilling technology was rigorously tested by a large team of microbiologists, geochemists, sedimentologists, physical property and logging specialists in order to evaluate its compatibility with the scientific goals. Whereas contamination control has become an integral measure of quality assurance in ODP/IODP expeditions with focus on subseafloor life, the riser drilling procedure applied during Expedition 337 required a more rigorous quality assurance/quality control program. As a result, a number of recommendations related to the future use of this technology in scientific ocean drilling can be made.

\subsection{Coring technology}

During Expedition 337, we performed spot coring, instead of conventional sequential coring strategy, using standard 8 $1 / 2^{\prime \prime}$ RCB coring and $105 / 8^{\prime \prime}$ LDC system. Both coring systems resulted in cores of excellent quality, including very hard carbonate-cemented nodules and conglomerates, from scientifically significant horizons. This spot-coring strategy 

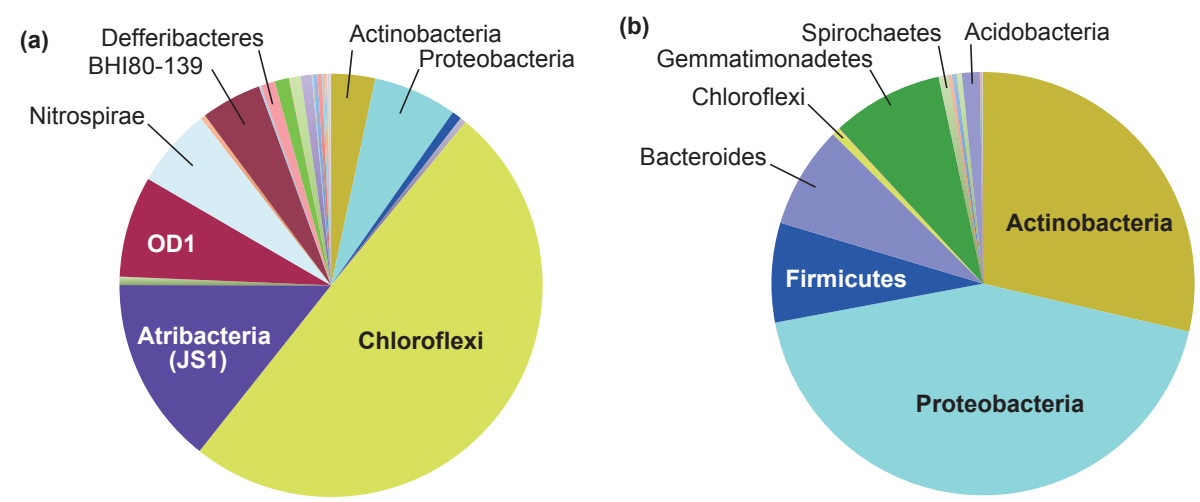

Figure 6. Taxonomic composition of indigenous bacterial communities based on 16S rRNA gene sequences from (a) shallow (five samples from 0 to 365 mb.s.f.; a total of 95179 sequence reads) and (b) deep (49 samples from 1.2 to $2.5 \mathrm{~km}$ b.s.f.; a total of 5957 sequence reads) sediment samples at Site C0020. This figure is slightly modified from Fig. S3 in Inagaki et al. (2015), and reprinted with permission from AAAS.

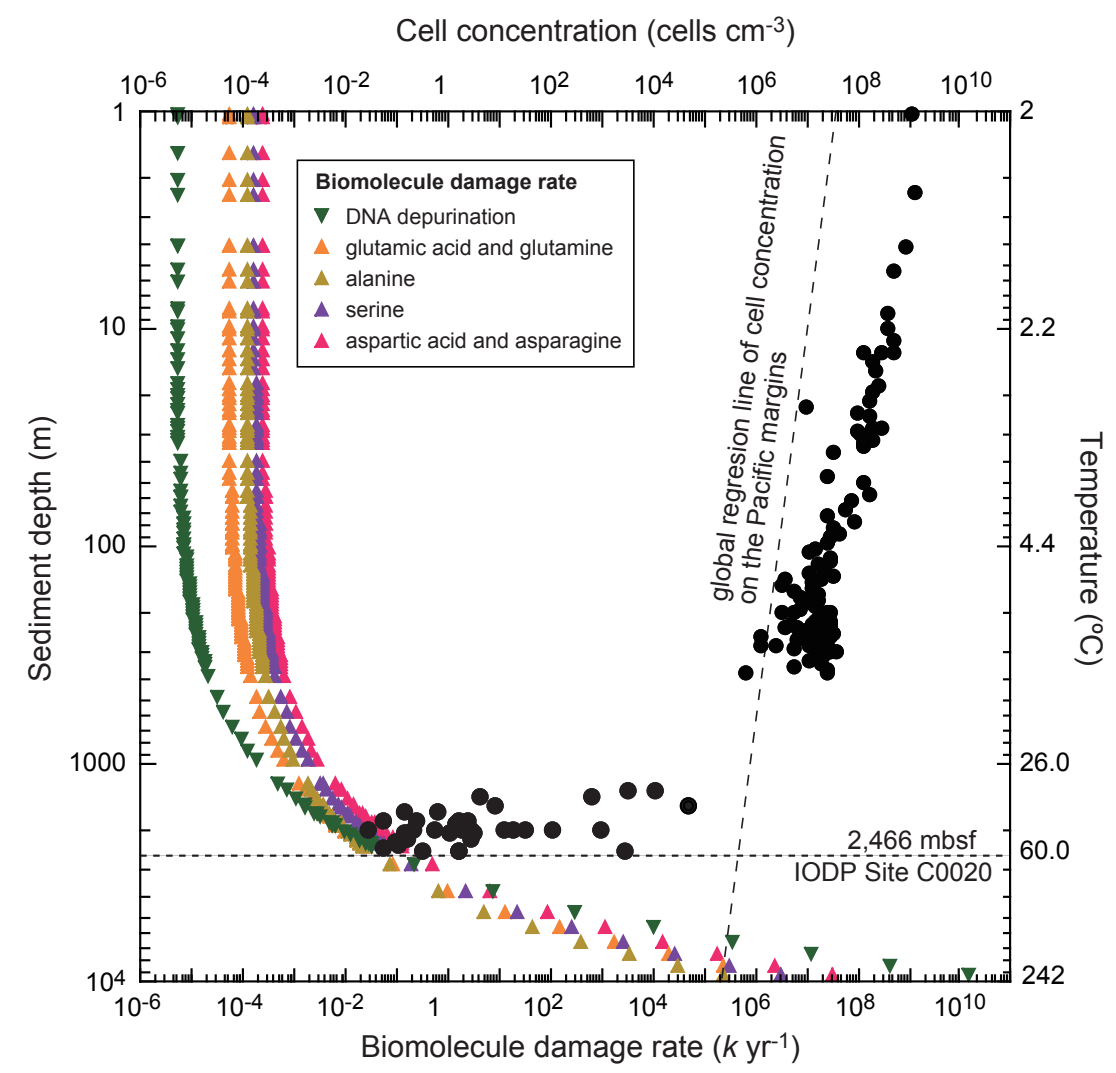

Figure 7. Depth profiles of cell concentrations (black plots), biomolecule damage rates, and in situ temperature at Site C0020. This figure is slightly modified from Fig. S14 in Inagaki et al. (2015), and reprinted with permission from AAAS.

is essential for reducing the cost and time for scientific riserdrilling operation. LDC cores maximize the probability to obtain non-contaminated massive core samples that are adequate for high recovery of pore water, allowing highly sensitive and specific biogeochemical and microbiological analyses. However, the use of an aluminum core liner required modification of the normal workflow and resulted in much longer time requirements for delivery of core material from the rig floor to the laboratory. Nevertheless, we processed LDC cores under anaerobic conditions and retrieved useful data and samples with relatively low levels of contamination for shipboard and shore-based analyses. Considering the high risk of drill mud and microbial contamination of the standard RCB core, it would be desirable to explore 
the potential use of improved LDC-type coring systems with non-metal core liner (e.g., glass fiber, carbon-reinforced plastic) as the standard spot-coring tool for future deep scientific drilling on the Chikyu.

\subsection{Drilling mud composition and sterilization}

The use of riser-drilling mud is essential for future deep scientific explorations. However, we will need to address both microbial and chemical contamination issues in order to optimize conditions for the examination of very deeply buried microbial communities and the chemical conditions in their habitat. For example, the mud used during Expedition 337 contained about $10^{8}$ contaminant cells $\mathrm{mL}^{-1}$, even though the fluid is alkaline and contains sterilizing chemicals. This high concentration of nonindigenous cells complicated precise detection of indigenous microbial life and its metabolic activities, and hampered the analysis of the chemical composition of pore water. To minimize the risk of drilling mudrelated sample contamination during future scientific riserdrilling expeditions, alternative drilling mud compositions (e.g., higher $\mathrm{pH}$ ) should be considered. For example, are there feasible technologies for mud sterilization that could be implemented without conflicting with operational demands for the deep drilling; can the organic additives that appear to nourish microbial communities be substituted with inorganic components? Can we develop in situ sampling devices for recovering non-contaminated and biologically pristine core and fluid samples?

\subsection{Use of deep-riser holes for experiments}

A positive aspect of the deep-riser drilling is the superior borehole stability supported by the use of high-viscosity mud that prevents possible collapse and flow-down of rubbly horizons such as coal and fault layers. This is not only useful for coring materials with high recovery rate, but also essential for successful completion of multiple deployments of logging tools, including downhole in situ fluid sampling and analysis by the QuickSilver MDT-Probe. With the combined use of borehole observatory sensors and subseafloor laboratory equipment, the maintenance of stable deep-riser boreholes will be highly useful for advanced subseafloor research in short- to long-term projects.

Last but not least, our expedition also provided a test ground for the use of riser-drilling technology to address geobiological and biogeochemical objectives and was therefore a crucial step toward the next phase of deep scientific ocean drilling. Since the riser system was originally developed by the petroleum industry, the Chikyu is equipped with a mature technology. However, the adaptation of this technology to the needs of basic science will be an important challenge that needs to be addressed as integral component in plans for the next riser missions. Implementation of "science- oriented" deep-riser drilling for high-quality samples would provide grand opportunities for Earth system sciences.

\section{Team members}

Monika Bihan, Stephen A. Bowden, Marshall Bowles, Marcus Elvert, Clemens Glombitza, Doris Gross, Guy J. Harrington, Verena Heuer, Wei-Li Hong, Tomoyuki Hori, Tatsuhiko Hoshino, Akira Ijiri, Hiroyuki Imachi, Motoo Ito, Masanori Kaneko, Mark A. Lever, Kevin Li, David Limmer, Yu-Shih Lin, Chang-Hong Liu, Barbara A. Methé, Sumito Morita, Yuki Morono, Masafumi Murayama, Naohiko Ohkouchi, Shuhei Ono, Young-Soo Park, Stephen C. Phillips, Xavier Prieto-Mollar, Marcella Purkey, Natascha Riedinger, Yoshinori Sanada, Justine Sauvage, Glen Snyder, Rita Susilawati, Yoshinori Takano, Wataru Tanikawa, Eiji Tasumi, Takeshi Terada, Hitoshi Tomaru, Elizabeth Trembath-Reichert, David T. Wang, and Yasuhiro Yamada.

Acknowledgements. The authors are grateful to the Integrated Ocean Drilling Program (IODP) and the Ministry of Education, Culture, Sports, Science, and Technology of Japan (MEXT) for providing an opportunity to explore the deep coalbed biosphere off Shimokita during Expedition 337. We thank all crews, drilling team members, and lab technicians on the drilling vessel Chikyu for supporting sampling and on-board measurements during the Chikyu shakedown cruise CK06-06 and the IODP Expedition 337. We also thank all shore-based scientists and curation staffs to support continuous research activities of Expedition 337. The IODP Expedition 337 was conducted as the first Complementary Proposal Project (CPP) supported in part by the Japan Society for the Promotion of Science (JSPS) Strategic Fund for Strengthening Leading-Edge Research and Development (to F.I. and JAMSTEC) and the JSPS Funding Program for Next Generation World-Leading Researchers (no. GR102 to F.I.).

Edited by: W. Sager

Reviewed by: B. Orcutt and one anonymous referee

\section{References}

Aoike, K. (Ed.): CDEX Laboratory Operation Report: CK06-06 D/V Chikyu shakedown cruise offshore Shimokita: Yokohama (CDEX-JAMSTEC), http://www.godac.jamstec.go.jp/catalog/ data/doc_catalog/media/CK06-06_902_all.pdf, 2007.

Aoike, K., Nishi, H., Sakamoto, T., Iijima, K., Tsuchiya, M., Taira, A., Kuramoto, S., Masago, H., and the Shimokita Core Research Group: Paleoceanographic history of offshore Shimokita Peninsula for the past 800,000 years based on primary analyses on cores recovered by D/V Chikyu during the shakedown cruises, Fossils, 87, 65-81 (in Japanese, with English abstract and figures), 2010.

Aoki, M., Kakiuchi, R., Yamaguchi, T., Takai, K., Inagaki, F., and Imachi, H.: Phylogenetic diversity of aprA genes in subseafloor sediments on the northwestern Pacific margin off Japan, Microb. Environ., 30, 276-280, 2015. 
Ciobanu, M.-C., Burgaud, G., Dufresne, A., Breuker, A., Rédou, V., Maamar, S. B., Gaboyer, F., Vandenabeele-Trambouze, O., Lipp, J. S., Schippers, A., Vandenkoornhuyse, P., Barbier, G., Jebbar, M., Godfroy, A., and Alain, K.: Microorganisms persist at record depths in the subseafloor of the Canterbury Basin, ISME J., 8, 1370-1380, 2014.

D’Hondt, S., Jørgensen, B. B., Miller, D. J., Batzke, A., Blake, R., Cragg, B. A., Cypionka, H., Dickens, G. R., Ferdelman, T., Hinrichs, K-U., Holm, N. G., Mitterer, R., Spivack, A., Wang, G., Bekins, B., Engelen, B., Ford, K., Gettemy, G., Rutherford, S. D., Sass, H., Skilbeck, C. G., Aiello, I . W., Guerin, G., House, C., Inagaki, F., Meister, P., Naehr, T., Niitsuma, S., Parkes, R. J., Schippers, A., Smith, D. C., Teske, A., Wiegel, J., Padilla, C. N., and Acosta, J. L. S.: Distributions of metabolic activities in deep subseafloor sediments, Science, 306, 2216-2200, 2004.

D’Hondt, S., Inagaki, F., Zarikian, C. A., Abrams, L. J., Dubois, N., Engelhardt, T., Evans, H., Ferdelman, T., Gribsholt, B., Harris, R. N., Hoppie, B. W., Hyun, J.-H., Kallmeyer, J., Kim. J., Lynch, J. E., McKinley, C. C., Mitsunobu, S., Morono, Y., Murray, R. W., Pockalny, R., Sauvage, J., Shimono, T., Shiraishi, F., Smith, D. C., Smith-Duque, C., Spivack, A. J., Steinsbu, B. O., Suzuki, Y., Szpak, M., Toffin, L., Uramoto, G., Yamaguchi, T. Y., Zhang, G., Zhang, X.-H., and Ziebis, W.: Presence of oxygen and aerobic communities from seafloor to basement in deep-sea sediment, Nat. Geosci., 8, 299-304, 2015.

Domitsu, H., Nishi, H., Uchida, J., Oda, M., Ogane, K., Taira, A., Aoike, K., and the Shimokita Microfossil Research Group: Age model of core sediments taken by D/V Chikyu during the shakedown cruises off Shimokita Peninsula, Fossils, 87, 47-64 (in Japanese, with English abstract and figures), 2010.

Futagami, T., Morono, Y., Terada, T., Kaksonen, A. H., and Inagaki, F.: Dehalogenation activities and distribution of reductive dehalogenase homologous genes in marine subsurface sediments, Appl. Environ. Microbiol., 75, 6905-6909, 2009.

Glombitza, C., Mangelsdorf, K., and Horsfield, B.: A novel procedure to detect low molecular weight compounds released by alkaline ester cleavage from low maturity coals to assess its feedstock potential for deep microbial life, Org. Geochem., 40, 175-183, 2009.

Gross, D., Bachtel, A., and Harrington, G. J.: Variability in coal facies as reflected by organic petrological and geochemical data in Cenozoic coal beds offshore Shimokita (Japan) - IODP Exp. 337, Int. J. Coal Geol., 152, 63-79, 2015.

Head, I. M., Jones, D. M., and Larter, S. R.: Biological activity in the deep subsurface and the origin of heavy oil, Nature, 426, 344352, 2003.

Hinrichs, K.-U., Hayes, J. M., Bach, W., Spivack, A. J., Hmelo, L. R., Holm, N. G., Johnson, C. G., and Sylva, S. P.: Biological formation of ethane and propane in the deep marine subsurface, P. Natl. Acad. Sci. USA, 103, 14684-14689, 2006.

Hinrichs, K.-U. and Inagaki, F.: Downsizing the deep biosphere, Science, 338, 204-205, 2012.

Imachi, H., Aoi, K., Tasumi, E., Saito, Y., Yamanaka, Y., Saito, Y., Yamaguchi, T., Tomaru, H., Takeuchi, R., Morono, Y., Inagaki, F., and Takai, K.: Cultivation of methanogenic community from subseafloor sediments using a continuous flow bioreactor, ISME J., 5, 1913-1925, 2011.

Imachi, H., Sakai, S., Lipp, J. S., Miyazaki, M., Saito, Y., Yamanaka, Y., Hinrichs, K.-U., Inagaki, F., and Takai, K.: Pelo- linea submarina gen. nov., sp. nov., an anaerobic, filamentous bacterium of the phylum Chloroflexi isolated from subseafloor sediment, Int. J. Syst. Evol. Microbiol., 64, 812-818, 2014.

Inagaki, F., Suzuki, M., Takai, K., Oida, H., Sakamoto, T., Aoki, K., Nealson, K. H., and Horikoshi, K.: Microbial communities associated with geological horizons in coastal sub-seafloor sediments from the Sea of Okhotsk, Appl. Environ. Microbiol., 69, 7224-7235, 2003.

Inagaki, F., Nunoura, T., Nakagawa, S., Teske, A., Lever, M., Lauer, A., Suzuki, M., Takai, K., Delwiche, M., Colwell, F. S., Nealson, K. H., Horikoshi, K., D’Hondt, S., and Jørgensen, B. B.: Biogeographical distribution and diversity of microbes in methane hydrate - bearing deep marine sediments on the Pacific Ocean margin, P. Natl. Acad. Sci. USA, 103, 2815-2820, 2006.

Inagaki, F., Hinrichs, K.-U., Kubo, Y., and the Expedition 337 Scientists: Deep coalbed biosphere off Shimokita: microbial processes and hydrocarbon system associated with deeply buried coalbed in the ocean, IODP Prel. Rept., 337, 1-62, doi:10.2204/iodp.pr.337.2012, 2012.

Inagaki, F., Hinrichs, K.-U., Kubo, Y., Bowles, M. W., Heuer, V. B., Hong, W.-L., Hoshino, T., Ijiri, A., Imachi, H., Ito, M., Kaneko, M., Lever, M. A., Lin, Y.-S., Methé, B. A., Morita, S., Morono, Y., Tanikawa, W., Bihan, M., Bowden, S. A., Elvert, M., Glombitza, C., Gross, D., Harrington, G. J., Hori, T., Li, K., Limmer, D., Liu, C.-H., Murayama, M., Ohkouchi, N., Ono, S., Park, Y.-S., Phillips, S. C., Prieto-Mollar, X., Purkey, M., Riedinger, N., Sanada, Y., Sauvage, J., Snyder, G., Susilawati, R., Takano, Y., Tasumi, E., Terada, T., Tomaru, H., Trembath-Reichert, E., Wang, D. T., and Yamada, Y.: Exploring deep microbial life down to $\sim 2.5 \mathrm{~km}$ below the ocean floor, Science, 349, 420-424, 2015.

Japan Natural Gas Association and Japan Offshore Petroleum Development Association (Eds.): Oil and Gas Resources in Japan (revised ed.), Tokyo, 1992 (in Japanese).

Jones, D. M., Head, I. M., Gray, N. D., Adams, J. J., Rowan, A. K., Aitken, C. M., Bennett, B., Huang, H., Brown, A., Bowler, B. F. J., Oldenburg, T., Erdmann, M., and Larter, S. R.: Crudeoil biodegradation via methanogenesis in subsurface petroleum reservoirs, Nature, 451, 176-180, 2008.

Kallmeyer, J., Pockalny, R., Adhikari, R. R., Smith, D. C., and D'Hondt, S.: Global distribution of microbial abundance and biomass in subseafloor sediment, P. Natl. Acad. Sci. USA, 109, 16213-16216, 2012.

Kawai, M., Futagami, T., Toyoda, A., Takaki, Y., Nishi, S., Hori, S., Arai, W., Tsubouchi, T., Morono, Y., Uchiyama, I., Ito, T., Fujiyama, A., Inagaki, F., and Takami, H.: High frequency of phylogenetically diverse reductive dehalogenase-homologous genes in deep subseafloor sedimentary metagenomes, Front. Microbiol., 5, 80, doi:10.3389/fmicb.2014.00080, 2014

Kawai, M., Uchiyama, I., Takami, H., and Inagaki, F.: Low frequency of endospore-specific genes in subseafloor sedimentary metagenomes, Environ. Microbiol. Rept., 7, 341-350, 2015.

Kobayashi, T., Koide, O., Mori, K., Shimamura, S., Matsuura, T., Miura, T., Takaki, Y., Morono, Y., Nunoura, T., Imachi, H., Inagaki, F., Takai, K., and Horikoshi, K.: Phylogenetic and enzymatic diversity of deep subseafloor aerobic microorganisms in organics- and methane-rich sediments off Shimokita Peninsula, Extremophiles, 12, 519-527, 2008. 
Lever, M. A., Alperin, M., Engelen, B., Inagaki, F., Nakagawa, S., Steinsbu, B. O., Teske, A., and IODP Expedition 301 Scientists: Trends in basalt and sediment core contamination during IODP Expedition 301, Geomicrobiol. J., 23, 517-530, 2006.

Lever, M. A., Rogers, K. L., Lloyd, K. G., Overmann, J., Schink, B., Thauer, R. K., Hoehler, T. M., and Jørgensen, B. B.: Life under extreme energy limitation: a synthesis of laboratory- and field-based investigations, FEMS Microbiol. Rev., 39, 688-728, doi:10.1093/femsre/fuv020, 2015.

Lipp, J. S., Morono, Y., Inagaki, F., and Hinrichs, K.-U.: Significant contribution of Archaea to extant biomass in marine subsurface sediments, Nature, 454, 991-994, 2008.

Masui, N., Morono, Y., and Inagaki, F.: Microbiological assessment of circulation mud fluids during the first operation of riser drilling by the deep-earth research vessel Chikyu, Geomicrobiol. J., 25, 274-282, 2008.

Miyazaki, M., Koide, O., Kobayashi, T., Mori, K., Shimanura, S., Nonoura, T., Imachi, H., Inagaki, F., Nagahama, T., Nogi, Y., Deguchi, S., and Takai, K.: Geofilum rubicundum gen. nov., sp. nov., isolated from deep subseafloor sediment, Int. J. Syst. Evol. Microbiol., 62, 1075-1080, 2012.

Miyazaki, M., Sakai, S., Ritalahti, K. M., Saito, Y., Yamanaka, Y., Saito, Y., Tame, A., Uematsu, K., Löffler, F. E., Takai, K., and Imachi, H.: Sphaerochaeta multiformis sp. nov., an anaerobic, psychrophilic bacterium isolated from subseafloor sediment, and emended description of the genus Sphaerochaeta, Int. J. Syst. Evol. Microbiol., 64, 4147-4154, 2014a.

Miyazaki, M., Sakai, S., Yamanaka, Y., Saito, Y., Takai, K., and Imachi, H.: Spirochaeta psychrophila sp. nov., a psychrophilic spirochaete isolated from subseafloor sediment, and emended description of the genus Spirochaeta, Int. J. Syst. Evol. Microbiol., 64, 2798-2804, 2014b.

Morono, Y. and Inagaki, F.: Automatic Slide-Loader Fluorescence Microscope for Discriminative Enumeration of Subseafloor Life, Sci. Dril., 9, 32-36, doi:10.2204/iodp.sd.9.05.2010, 2010.

Morono, Y., Terada, T., Masui, N., and Inagaki, F.: Discriminative detection and enumeration of microbial life in marine subsurface sediments, ISME J., 3, 503-511, 2009.

Morono, Y., Terada, T., Nishizawa, M., Ito, M., Hillion, F., Takahata, N., Sano, Y., and Inagaki, F.: Carbon and nitrogen assimilation in deep subseafloor microbial cells, P. Natl. Acad. Sci. USA, 108, 18295-18300, 2011.

Morono, Y., Terada, T., Kallmeyer, J., and Inagaki, F.: An improved cell separation technique for marine subsurface sediments: Applications for high-throughput analysis using flow cytometry and cell sorting, Envion. Microbiol., 15, 2841-2849, 2013.

Morono, Y., Terada, T., Hoshino, T., and Inagaki, F.: Hot-alkaline DNA extraction method for deep subseafloor archaeal communities, Appl. Environ. Microbiol., 80, 1985-1994, 2014.
Nunoura, T., Takaki, Y., Shimamura, S., Kakuta, J., Kazama, H., Hirai, M., Masui, N., Tomaru, H., Morono, Y., Imachi, H., Inagaki, F., and Takai, K.: Variance and potential niche separation of microbial communities in subseafloor sediments off Shimokita Peninsula, Japan, Environ. Microbiol., doi:10.1111/1462-2920.13096, in press, 2016.

Osawa, M., Nakanishi, S., Tanahashi, M., Oda, H., and Sasaki, A.: Structure, tectonic evolution and gas exploration potential of offshore Sanriku and Hidaka provinces, Pacific Ocean, off northern Honshu and Hokkaido, Japan, J. Jpn. Assoc. Pet. Technol., 67, 38-51 (in Japanese, with English abstract and figures), 2002.

Parkes, R. J., Cragg, B. A., Bale, S. J., Getliff, J. M., Goodman, K., Rochelle, P. A., Fry, J. C., Weightman, A. J., and Harvey, S. M.: Deep bacterial biosphere in Pacific Ocean sediments, Nature, 371, 410-413, 1994.

Seno, T., Sakurai, T., and Stein, S.: Can the Okhotsk plate be discriminated from the North American plate?, J. Geophys. Res.Sol. Ea., 101, 11305-11315, 1996.

Stolper, D. A., Lawson, M., Davis, C. L., Ferreira, A. A., Santos Neto, E. V., Lewan, M. D., Martini, A. M., Tang, Y., Schoell, M., Sessions, A. L., and Eiler, J. M.: Formation temperatures of thermogenic and biogenic methane, Science, 344, 1500-1503, 2014.

Strąpoć, D., Picardal, F. W., Turich, C., Schaperdoth, I., Macalady, J. L., Lipp, J. S., Lin, Y.-S., Ertefai, T. F., Schubotz, F., Hinrichs, K.-U., Mastalerz, M., and Schimmelmann, A.: Methaneproducing microbial community in a coal bed of the Illinois basin, Appl. Environ. Microbiol., 74, 2424-2432, 2008.

Strąpoć, D., Mastalerz, M., Dawson, K., Macalady, J., Callaghan, A. V., Wawrik, B., Turich, C., and Ashby, M.: Biogeochemistry of microbial coal-bed methane, Annu. Rev. Earth Pl. Sc., 39, 617656, 2011.

Takai, K., Abe, M., Miyazaki, M., Koide, O., Nunoura, T., Imachi, H., Inagaki, F., and Kobayashi, T.: Sunxiuqinia faeciviva sp. nov., a facultatively anaerobic organoheterotroph of the Bacteroidetes isolated from deep subseafloor sediment, Int. J. Syst. Evol. Microbiol., 63, 1062-1069, 2012.

Tanikawa, W., Tadai, O., Morita, S., Lin, W., Yamada, Y., Sanada, Y., Moe, K., Kubo, Y., and Inagaki, F.: Thermal properties and thermal structure in the deep-water coalbed basin off the Shimokita Peninsula, Japan, Mar. Petrol. Geol., 73, 445-461, 2016.

Wang, D. T., Gruen, D. S., Sherwood Lollar, B., Hinrichs, K.-U., Stewart, L. C., Holden, J. F., Hristov, A. N., Pohlman, J. W., Morrill, P. L., Könneke, M., Delwiche, K. B., Reeves, E. P., Sutcliffe, C. N., Ritter, D. J., Seewald, J. S., McIntosh, J. C., Hemond, H. F., Kubo, M. D., Cardace, D., Hoehler, T. M., and Ono, S.: Nonequilibrium clumped isotope signals in microbial methane, Science, 348, 428-431, 2015. 